REPORTS OF MORPHOLOGY
Official Journal of the Scientific Society of Anatomists,
Histologists, Embryologists and Topographic Anatomists
of Ukraine
journal homepage: https://morphology-journal.com

\title{
Anatomo-functional characteristics of the pelvic organs in women with habitual miscarriage and chronic endometritis
}

Nevhadovska P.M., Chechuga S.B., Nochvina E.A., Dzis N.P.

National Pirogov Memorial Medical University, Vinnytsya, Ukraine

\section{ARTICLE INFO}

Received: 1 September, 2020

Accepted: 5 October, 2020

UDC: $618.39-08-07: 618.14-002$

\section{CORRESPONDING AUTHOR}

e-mail: nata.d55@ukr.net

Dzis N.P.
Chronic endometritis is a clinical and morphological syndrome, which under the influence of an infectious agent contributes to the violation of cyclic biotransformation and reciprocity of the endometrium. In the diagnosis of gynecological pathology, in particular chronic endometritis, or habitual miscarriage on the background of chronic endometritis, ultrasonography is a mandatory, non-invasive and highly specific method of research. The aim of the study was to assess the anatomical and functional condition of the pelvic organs in women with habitual miscarriage and chronic endometritis using ultrasound (ultrasound and Doppler) criteria. We examined 98 women of childbearing age who applied to the Inomed clinic in the city of Vinnytsia during 2019-2020. Patients were divided into two groups: the main group - 68 women with habitual miscarriage and chronic endometritis; control group - 30 re-pregnant women without previous pregnancy loss. Initially, ultrasound examination (ultrasound) of the pelvic organs was performed on day 5-7 of the menstrual cycle, and to monitor folliculogenesis, the study was repeated on day 13-17 of the cycle. One of the main signs of chronic endometritis is the heterogeneity of the structure of the endometrium, which was found in the vast majority of examined patients of the main group $(80.88 \%$ at $n=68)$. When determining the thickness of the endometrium, two diametrically opposite processes were established, namely: atrophy (39.71\% at $n=68$ ) and atypical glandular hyperplasia (22.05\% at $n=68$ ). In the second half of the menstrual cycle there was a significant thinning of the endometrial layer $<0.6 \mathrm{~cm}$. In the control group during the ultrasound examination revealed the following disorders: increased uterine peristalsis, dilation of the arcuate plexus, the heterogeneity of the subendometrial layer, and when re-ultrasound took into account the data of folliculogenesis. Follicular cysts were detected in $10.3 \%$ of cases in the main group and $3.3 \%$ in the control group of women. At the time of re-ultrasound in each ovary was observed 5-8 antral follicles (the size of which ranged from $6.8 \mathrm{~mm}$ to 11.5 $\mathrm{mm}$ ) with the presence of one dominant, the size of which ranged from 18.2 to $23.4 \mathrm{~mm}$. In order to increase the informativeness of ultrasound, Doppler was additionally performed. Thus, ultrasonography is a highly specific method for determining the anatomical and functional characteristics of the pelvic organs, in particular the pathology of the endometrium in women with habitual miscarriage. The main ultrasound characteristics of chronic endometritis, as one of the causes of reproductive losses, are changes in endometrium structure, thickness, the presence of additional structures (polyps) and fluid component. Informativeness of ultrasound examination of structural changes in the endometrium in chronic endometritis is complemented by Doppler characteristics of blood flow in the basal and spiral arteries of the uterus.

Keywords: chronic endometritis, habitual miscarriage, ultrasonography.

\section{Introduction}

Against the background of deteriorating demographic situation in Ukraine, one of the priority medical and social tasks is to preserve the reproductive health of women. Unfortunately, about $15-20 \%$ of normal pregnancies under the influence of certain factors go to the section "reproductive losses".
The complexity of diagnosis and treatment of habitual miscarriage for many years is due to a wide range of endogenous and exogenous etiological factors. Despite the fact that a clear determination has not yet been established, there are a number of background diseases that contribute 
to abortion. Today, known causes of miscarriage are genetic (13\%), anatomical (10-15\%), endocrine, immune, infectious factors, "male factor", etc. [28].

Inflammatory diseases of the pelvic organs have a significant negative impact on the health of women of the most active reproductive age (due to the peculiarities of pathogenesis) [13,22]. One such disease is chronic endometritis (CE).

The problem of chronic endometritis remains extremely relevant because this "uterine" factor often leads to menstrual and generative dysfunction: miscarriage, infertility $[8,14,20$, 26].

Chronic endometritis is a clinical and morphological syndrome in which due to persistent damage to the endometrium by infectious agents, multiple secondary morphofunctional changes occur, which disrupt the cyclic biotransformation and receptivity of the uterine mucosa [7, $19,24]$. Its course is often asymptomatic or coexists with mild nonspecific symptoms along with pelvic pain, abnormal uterine bleeding, vaginal discharge or pain during intercourse [9].

Given the lack of a pronounced clinical picture, modern diagnosis of $C E$ is based on the integrated use of history, clinic, diagnostic methods and their evaluation [17, 23, 26]. Among the additional methods of examination, one of the mandatory is ultrasound, as a non-invasive and highly specific method of visualizing the condition of the reproductive system. The sensitivity of the method is $78.1 \%$, and its specificity is $82.5 \%$ [2]. If we consider ultrasound only in the diagnosis of habitual miscarriage on the background of chronic endometritis, this study is not a highly specific method and belongs to the auxiliary. This judgment is shared by Groth, J.V. and co-authors, confirming this in their research $[6,16]$. However, it should be noted the importance of ultrasound in detecting the synchrony of the transformation of the endometrium by phases of the menstrual cycle (MC) to diagnose CE and monitor the effectiveness of treatment and rehabilitation of fertility [21].

To increase the informativeness of ultrasound, it is recommended to use new technologies in Doppler: color U3D Doppler, three-dimensional imaging [21]. Impaired blood flow in the vessels of the uterus with a predominance of damage at the level of the basal and spiral arteries, as well as difficulties in visualizing the terminal artery indicate a strong violation of tissue perfusion due to chronic inflammation [12].

The aim of the study was to assess the anatomical and functional condition of the pelvic organs in women with habitual miscarriage and chronic endometritis using ultrasound (ultrasound and Doppler) criteria.

\section{Materials and methods}

In order to study the main ultrasound features of the pelvic organs in women diagnosed with "habitual miscarriage on the background of endometritis" were examined 98 women of childbearing age who applied to the clinic Innomed Vinnytsia during 2019-2020. All women applied to the clinic at the pre-pregnancy stage and continued their follow-up during pregnancy.

During the study, patients were divided into 2 clinical groups:

The main group - 68 women with a diagnosis of habitual miscarriage on the background of chronic endometritis. Criteria for inclusion of patients in the main group were the following: the presence of two or more reproductive losses in the anamnesis in the form of miscarriage, the absence of an embryo in the developing fetal egg or stillbirth; confirmed diagnosis of "chronic endometritis" by immunohistochemical determination of syndecan-1 (sampling of endometrium in the selection of patients was performed by hysteroscopy or pipette biopsy followed by immunohistochemical analysis of the material). The control group consisted of 30 re-pregnant women without a history of reproductive loss.

All patients underwent a typical general clinical and gynecological examination. Ultrasound examination of the pelvic organs to determine their anatomical and functional status and pathognomonic criteria of chronic endometritis was performed using the device Voluson E8 Expert. For a qualitative and most accurate assessment of the condition of the uterine cavity, this procedure was initially performed on day 5-7 of the menstrual cycle, and to monitor folliculogenesis, the study was repeated on day 13-17 of the cycle.

\section{Results}

The age of patients ranged from 19 to 35 years (Table 1). The average age of the examined patients of the main group was $27.25 \pm 0.29$ years, which probably did not differ from the age of women in the control group $26.74 \pm 0.18$ years. The indicator of the degree of probability (p) between the two comparative values was considered reliable at $p<0.05$.

Ultrasound of the main group of patients showed the following pathological changes, indicating chronic endometritis as the main etiological factor of habitual miscarriage: uneven endometrial contour, increased echogenicity in the first phase of the menstrual cycle and heterogeneous echostructure of the endometrium, diffuse focal changes of the myometrium and others. These pathological changes were observed only in isolated cases in re-pregnant women who formed a control group, which once again confirms the etiopathogenetic link of habitual

Table 1. The age structure of surveyed women.

\begin{tabular}{|c|c|c|c|c|}
\hline \multirow{2}{*}{ Age } & \multicolumn{2}{|c|}{ Main group $(n=68)$} & \multicolumn{2}{r|}{ Control group $(n=30)$} \\
\cline { 2 - 5 } & Absolute numbers & $\%$ & Absolute numbers & $\%$ \\
\hline $19-24$ & 15 & $22.06^{* *}$ & 6 & 20.0 \\
\hline $25-29$ & 36 & $52.94^{* *}$ & 15 & 50.00 \\
\hline $30-35$ & 17 & $25.00^{* *}$ & 9 & 30.00 \\
\hline
\end{tabular}

Notes: ${ }^{* *}$ - main group/control group $p>0,05$. 
Table 2. Ultrasound characteristics of the endometrium in the examined women.

\begin{tabular}{|c|c|c|c|c|c|}
\hline \multirow{3}{*}{ Sign } & \multicolumn{5}{|c|}{ Detection frequency } \\
\hline & \multicolumn{2}{|c|}{ Main group $(n=68)$} & \multicolumn{2}{|c|}{ Control group $(n=30)$} & \multirow{2}{*}{$\begin{array}{c}\text { Total } \\
\text { number }\end{array}$} \\
\hline & Absolute numbers & $\%$ & Absolute numbers & $\%$ & \\
\hline Heterogeneity of the endometrial structure & 55 & $80.88^{*}$ & 2 & 6.7 & 57 \\
\hline Endometrial midline is blurred, uneven or not visualized & 35 & 51.47 & 0 & 0 & 35 \\
\hline Fuzzy outer contour of the M-echo & 29 & 42.65 & 0 & 0 & 29 \\
\hline Hyperechogenic outer contour of the M-echo & 26 & 38.24 & 0 & 0 & 26 \\
\hline Endometrial atrophy & 27 & 39.71 & 0 & 0 & 27 \\
\hline Increasing the echogenicity of the endometrium in the 1 st phase of the cycle & 23 & 33.82 & 0 & 0 & 23 \\
\hline Dilation of the uterine cavity due to fluid content & 23 & 33.82 & 0 & 0 & 23 \\
\hline Endometrial micropolyps and polyps & 22 & 32.35 & 0 & 0 & 22 \\
\hline Decreased echogenicity of the endometrium in the 2 nd phase of the cycle & 19 & 27.94 & 0 & 0 & 19 \\
\hline Hyperechoic endometrial midline & 18 & 26,47 & 0 & 0 & 18 \\
\hline Expansion of the arcuate plexus & 13 & $19.12^{*}$ & 3 & 10,0 & 16 \\
\hline Asymmetry of endometrial thickness & 15 & $22.06^{*}$ & 2 & 6,7 & 17 \\
\hline Thickening of the endometrium more than $15 \mathrm{~mm}$ & 15 & 22.06 & 0 & 0 & 15 \\
\hline Heterogeneity of the subendometrial layer & 8 & 11.76 & 3 & 10,0 & 11 \\
\hline Gas bubbles in the endometrium or uterine cavity & 7 & 10.29 & 0 & 0 & 7 \\
\hline Increased uterine motility & 5 & 7.35 & 3 & 10,0 & 8 \\
\hline Synechia & 2 & 2.94 & 0 & 0 & 2 \\
\hline
\end{tabular}

Notes: * - main group/control group $p<0,05$.

miscarriage with chronic inflammation of the endometrium. A more detailed description of ultrasound changes and the frequency of their detection is presented in Table 2.

Among women in the control group, the following ultrasound disorders were detected: increased uterine motility, dilation of the arcuate plexus, heterogeneity of the subendometrial layer. At the same time, in each patient of the main and comparison groups there were from 3 to 5 main above-mentioned ultrasound diagnostic criteria of chronic endometritis. It should be noted that the heterogeneity of the structure of the endometrium is one of the main signs of chronic endometritis, as it occurs in the vast majority of examined patients of the main group $(80.88 \%$ at $\mathrm{n}=68$ ).

In order to increase the informativeness of the ultrasound examination, dopplerometry was additionally performed. Standard Doppler parameters were evaluated, namely the indices of pulsation and resistance, blood flow velocity in the uterine vessels. We found that in women of the main group, the indices of resistance and pulsation almost doubled, in contrast to the decrease in blood flow in the basal and spiral arteries of the uterus and varicose veins of the uterus, relative to the control group - the above pathological changes were not detected.

\section{Discussion}

According to various authors, the sonographic signs of chronic endometritis are as follows: change in the thickness of the endometrium, its thinning in the second half of the $\mathrm{MC}<0.6 \mathrm{~cm}$; expansion of the uterine cavity to $0.4-0.7 \mathrm{~cm}$ after menstruation with asymmetry of the anterior and posterior walls of the uterus; uneven contours of the endometrium; heterogeneity of the echostructure of the endometrium; appearance of increased echogenicity of areas of different sizes and shapes in the proliferative phase, hyperechogenic inclusions in the basal layer of the endometrium; synechiae in the uterine cavity; diffuse focal and cystic changes in the subendometrial zone; appearance of gas bubbles [10, 14, 19, 24]. The above criteria were recorded in the course of our research.

The fact of heterogeneity of the endometrial structure as one of the main features of chronic endometritis (it was established by us in most of the examined patients of the main group) is repeatedly confirmed in the works of other authors [15, 18].

Regarding the thickness of the endometrium, the data are not so unambiguous, because there are two diametrically opposed processes, namely - atrophy $(39.71 \%$ at $n=68)$ and atypical glandular hyperplasia $(22.05 \%$ at $n=68)$. However, there is a clear advantage in the direction of thinning of the endometrial layer $<0.6 \mathrm{~cm}$ in the second half of the menstrual cycle. Atrophic changes of the endometrium in more than a third of the surveyed women diagnosed with "Chronic endometritis" also notes S.M. Kornienko and fixes this criterion at $44.4 \%$ [11].

It is worth noting the following disappointing feature 
(excluding the vector of change of the endometrial layer): in most women with habitual miscarriage on the background of chronic endometritis $(61.76 \%$ at $n=68)$ the thickness of the endometrium does not correspond to the phase of the cycle. In turn, this indicates a violation of the transformation of the endometrium, and, consequently, the difficulty of subsequent implantation. After all, the condition for successful implantation and further normal development of the fertilized egg is the morphofunctional fullness of the endometrium, which is characterized by adequate receptor activity that ensures interaction with the embryo, as well as an adequate immune response of the woman.

In addition, a third of the studied women have dilatation of the uterine cavity to $0.5-0.7 \mathrm{~cm}$, fuzzy hyperechogenic outer contour of the M-echo, serosometer, as well as the presence of polyps in the uterine cavity, which is an important diagnostic sign. E. Cicinelli in his research repeatedly draws our attention to micropolyps as a reliable criterion for the diagnosis of "Chronic Endometritis". Although the rate of $11.7 \%$ detection of micropolyps in the studied women is not large, but $93.7 \%$ of these cases received histological confirmation of $\mathrm{CE}$, which is statistically important $[4,5]$. The presence of micropolyps - as predictors of the development of chronic endometritis - was confirmed in other scientific papers [3, 25, 27, 29]. Regarding our research, we recorded this figure in $32.35 \%$ of women in the main group.

During repeated ultrasound examination took into account the data of folliculogenesis, as one of the main functional characteristics of the pelvic organs. The analysis of the results showed that among the examined women 9 had follicular cysts - $7(10.3 \%)$ cases in the main group and $1(3.3 \%)$ - in the control group, in other women no pathology was detected. The size of the ovaries was within normal limits. At the time of repeated ultrasound, 5-8 antral follicles were observed in each ovary (their size ranged from $6.8 \mathrm{~mm}$ to $11.5 \mathrm{~mm}$ ), with one dominant, the size of which ranged from 18.2 to $23.4 \mathrm{~mm}$.

After Doppler, in women diagnosed with habitual miscarriage on the background of chronic endometritis found an increase of almost 2 times the indices of resistance and pulsation with a decrease in blood flow in the basal and spiral arteries of the uterus and varicose veins, as evidenced by most modern studies [1, 12], in

\section{List of references}

[1] Avramenko, N. V., \& Postolenko, V. Y. (2020). Possibilities of modern diagnostic methods in women with infertility in chronic endometritis. Bukovynian Medical Bulletin, 24(1), 93, 3-9. https://doi.org/10.24061/2413-0737.XXIV.1.93.2020.1

[2] Bochkov, V. V., Plekhanov, A. N., \& Tsydenova, Ts. B. (2015). Chronic nonspecific endometritis: epidemiology, etiology, pathogenesis, risk factors, diagnosis. Bulletin of the Buryat State University. Medicine and Pharmacy, 12, 30-38.

[3] Cicinelli, E., Matteo, M., Tinelli, R., Lepera, A., Alfonso, R., Indraccolo, U. ... Resta, L. (2015). Prevalence of chronic endometritis in repeated unexplained implantation failure and which the presence of hypovascularization of the uterus in all morphotypes of chronic endometritis, and an increase in the resistance index is most characteristic for hypoplastic type.

Although pelvic ultrasonography is not a highly specific method for diagnosing habitual miscarriage in chronic endometritis, monitoring endometrial transformation and monitoring the effectiveness of treatment and rehabilitation of fertility by ultrasound is a promising approach in the examination and treatment of this group of patients. For a clearer identification of chronic endometritis as the main etiological factor of gestational loss in the future requires endometrial biopsy in combination with immunohistochemical analysis.

\section{Conclusions}

The results of the above studies indicate that ultrasonography is an indispensable method of diagnosis in obstetrics and gynecology in general and in the diagnosis of chronic endometritis in particular, but for a clearer diagnosis requires a comprehensive approach with analysis of clinical data and the results of several additional research methods.

1. The main ultrasound criteria for chronic endometritis in women diagnosed with habitual miscarriage are: inhomogeneous endometrial echostructure, uneven endometrial contour, increased echogenicity in the first phase of the menstrual cycle, endometrial thickness violation, enlargement of the uterine cavity, fuzzy hyperechogenic outer contour of the M-echo, serosometer, as well as the presence of polyps in the uterine cavity.

2. The thickness and structure of the endometrium is important for prognostic value as an indicator of successful implantation. In $61.76 \%$ of the examined women, the thickness of the endometrium did not correspond to the phase of the cycle, which indicated problems of cyclic transformation in the peri-implantation period.

3. In order to increase the informativeness of ultrasound examination, Doppler is performed. Doppler echo method indicates the following criteria for chronic endometritis: increase in pulsation index and resistance almost twice against the background of reduced blood flow in the basal and spiral arteries of the uterus and varicose of veins.

the IVF success rate after antibiotic therapy. Human Reproduction, 30(2), 323-330. https://doi.org/10.1093/humrep/ deu292

[4] Cicinelli, E., Resta, L., Nicoletti, R., Tartagni, M., Marinaccio, M., Bulletti, C., \& Colafiglio, G. (2005). Detection of chronic endometritis at fluid hysteroscopy. Journal of Minimally Invasive Gynecology, 12(6), 514-518. https://doi.org/10.1016/ j.jmig.2005.07.394

[5] Cicinelli, E., Resta, L., Nicoletti, R., Zappimbulso, V., Tartagni, M., \& Saliani, N. (2005). Endometrial micropolyps at fluid hysteroscopy suggest the existence of chronic endometritis. 
Human Reproduction (Oxford, England), 20(5), 1386-1389. https://doi.org/10.1093/humrep/deh779

[6] Groth, J. V. (2018). Chronic endometritis and the plasma cell, fact versus fiction. Fertility and Sterility, 109(5), 788. https:// doi.org/10.1016/j.fertnstert.2018.02.116

[7] Kishakevich, I. T., Kotsabin, N. V., \& Radchenko, V. V. (2017). Endometrium in the focus of gynecologist: the role of hysteroscopy and immunohistochemistry in the diagnosis of chronic endometritis, the choice of treatment. Reproductive Endocrinology, 34(2), 24-27. ISSN: 2309-4117.

[8] Kitaya, K., Matsubayashi, H., Yamaguchi, K., Nishiyama, R., Takaya, Y., Ishikawa, T. ... Yamada, H. (2016). Chronic Endometritis: Potential Cause of Infertility and Obstetric and Neonatal Complications. American Journal of Reproductive Immunology, 75(1), 13-22. https://doi.org/10.1111/aji.12438

[9] Kitaya, K., Takeuchi, T., Mizuta, S., Matsubayashi, H., \& Ishikawa, T. (2018). Endometritis: new time, new concepts. Fertility and Sterility, 110(3), 344-350. https://doi.org/10.1016/ j.fertnstert.2018.04.012

[10] Kondratyuk, V. V. (2015). Instrumental research methods in gynecology. Medical Aspects of a Woman's Health, 90(4), 10-19.

[11] Kornienko, S. M. (2017). Ultrasonographic criteria in the differential diagnosis of endometrial polyps and chronic endometritis. Bulletin of Vinnytsia National Medical University, 21(1/1), 49-54.

[12] Kozyreva, E. V., Tyurina, N. A., Andreeva, N. A., Merenkova, I. V., \& Kuznetsova, M. A. (2019). Ultrasonic and dopplerometric characteristics of chronic endometritis of women with infertility and miscarriage. Electronic Journal of General Medicine, 16(2), em108. https://doi.org/10.29333/ejgm/106075

[13] Kuznetsova, A. V. (2000). Chronic endometritis. Archive of Pathology, 3, 48-52.

[14] Lisitsa, V. (2018). Management of patients with inflammatory diseases of the pelvic organs. Review of the recommendations of the British Association for Sexual Health and HIV. Medical Aspects of Women's Health, 3, 17-23.

[15] Liu, Y., Chen, X., Huang, J., Wang, C. C., Yu, M. Y., Laird, S., \& $\mathrm{Li}, \mathrm{T}$. C. (2018). Comparison of the prevalence of chronic endometritis as determined by means of different diagnostic methods in women with and without reproductive failure. Fertility and Sterility, 109(5), 832-839. https://doi.org/10.1016/ j.fertnstert.2018.01.022

[16] Moreno, I., Cicinelli, E., Garcia-Grau, I., Gonzalez-Monfort, M., Bau, D., Vilella, F.... Simon, C. (2018). The diagnosis of chronic endometritis in infertile asymptomatic women: a comparative study of histology, microbial cultures, hysteroscopy, and molecular microbiology. American Journal of Obstetrics and Gynecology, 218(6), 602. https://doi.org/10.1016/ j.ajog.2018.02.012

[17] Moreno, I., Codoner, F. M., Vilella, F., Valbuena, D., MartinezBlanch, J. F., Jimenez-Almazan, J. ... Simon, C. (2016). Evidence that the endometrial microbiota has an effect on implantation success or failure. American Journal of Obstetrics and Gynecology, 215(6), 684-703. https://doi.org/ 10.1016/j.ajog.2016.09.075

[18] Ni, J., Han, B., Liang, J., \& Wang, F. (2019). Three-dimensional 3D ultrasound combined with power Doppler for the differential diagnosis of endometrial lesions among infertile women. International Journal of Gynaecology and Obstetrics, 145(2), 212-218. https://doi.org/10.1002/ijgo.12787

[19] Radko, V. Yu. (2016). Prevention of miscarriage in women with a history of chronic endometritis. Diss. abstract for the degree of Cand. of Med. Scien.: 14.01.01. Kyiv: National Medical Academy of Postgraduate Education P.L. Shupik.

[20] Sfakianoudis, K., Simopoulou, M., Nikas, Y., Rapani, A., Nitsos, N., Pierouli, K. ... Pantos, K. (2018). Efficient treatment of chronic endometritis through a novel approach of intrauterine antibiotic infusion: a case series. BMC Women's Health, 18(1), 197. https://doi.org/10.1186/s12905-018-0688-8

[21] Snopkova, L. V., Cherepova, V. I., Kandyba, L. I., \& Sikal, I. M. (2019). Modern possibilities of diagnosis of chronic endometritis. Problems of Continuing Medical Education and Science, 35(3), 68-72. https://doi.org/10.31071/ promedosvity2019.03.068

[22] Sun, J. (2010). Vitamin D and mucosal immune function. Current Opinion in Gastroenterology, 26(6), 591-595. doi: 10.1097/ MOG.0b013e32833d4b9f

[23] Troedsson, M. H., \& Woodward, E. M. (2016). Our current understanding of the pathophysiology of equine endometritis with an emphasis on breeding-induced endometritis. Reproductive Biology, 16(1), 8-12. https://doi.org/10.1016/ j.repbio.2016.01.003

[24] Veropotvelyan, P. N., Tsekhmistrenko, I. S., Veropotvelyan, N. P., \& Guzhevskaya I. V. (2016). A practitioner's perspective on pelvic inflammatory disease in women. Medical Aspects of Women's Health, 101(4), 46-53. ISSN: 2311-5335

[25] Viana, G. A., Cela, V., Ruggiero, M., Pluchino, N., Genazzani, A. R., \& Tantini, C. (2015). Endometritis in Infertile Couples: The Role of Hysteroscopy and Bacterial Endotoxin. JBRA assisted reproduction, 19(1), 21-23. https://doi.org/10.5935/ 1518-0557.20150006

[26] Vovk, I. B., Timchenko, O. I., Revenko, O. O., \& Revenko, O. M. (2014). Abortion is a predictor of a woman's reproductive health. Health of Ukraine, 44-47. Taken from: http://healthua.com/pics/pdf/ZU_2014_Akusher_1/44-47.pdf

[27] Yang, R., Du, X., Wang, Y., Song, X., Yang, Y., \& Qiao, J. (2014). The hysteroscopy and histological diagnosis and treatment value of chronic endometritis in recurrent implantation failure patients. Archives of Gynecology and Obstetrics, 289(6), 13631369. https://doi.org/10.1007/s00404-013-3131-2

[28] Zhabchenko, I. A. (2018). Habitual miscarriage: what to do and what not to do (Review). Woman's Health, 127(1), 9-13. doi: 10.15574/hw.2018.127.9

[29] Zolghadri, J., Momtahan, M., Aminian, K., Ghaffarpasand, F., \& Tavana, Z. (2011). The value of hysteroscopy in diagnosis of chronic endometritis in patients with unexplained recurrent spontaneous abortion. European Journal of Obstetrics, Gynecology, and Reproductive Biology, 155(2), 217-220. https://doi.org/10.1016/j.ejogrb.2010.12.010

\section{АНАТОМО-ФУНКЦІОНАЛЬНА ХАРАКТЕРИСТИКА ОРГАНІВ МАЛОГО ТАЗА У ЖІНОК ЗІ ЗВИЧНИМ НЕВИНОШУВАННЯМ ВАГІТНОСТI ТА ХРОНІЧНИМ ЕНДОМЕТРИТОМ \\ Невгадовська П.М., Чечуга С.Б., Ночвіна О.А., Дзісь Н.П.}

Хронічний ендометрит - це клініко-морфологічний синдром, який під впливом інфекційного агента сприяє порушенню циклічної біотрансформації та рециптивності ендометрія. В діагностиці гінекологічної патології, зокрема хронічного ендометриту, або звичного викидня на тлі хронічного ендометриту, ультрасонографія являється обов'язковим, неінвазивним та високо специфічним методом дослідження. Мета роботи - оцінити анатомо-функціональний стан органів малого таза у жінок зі 
звичним невиношуванням вагітності та хронічним ендометритом за допомогою ультразвукових (ехографрічних та доплерометричних) критеріїв. Ми обстежили 98 жінок дітородного віку, які звертались до клініки Іномед у місті Вінниця у період 2019-2020 років. Хворі були розділені на 2 групи: основна група - 68 жінок зі звичним викиднем та хронічним ендометритом; контрольна група - 30 повторно вагітних жінок без попередньої втрати вагітності. Спочатку ультразвукове дослідження (УЗД) органів малого таза проводили на 5-7 день менструального циклу, а для моніторингу фолікулогенеза дослідження повторювали на 13-17 день циклу. Одним з основних ознак хронічного ендометриту є неоднорідність будови ендометрію, котра була встановлена у переважної більшості обстежених пацієнтів основної групи (80,88\% при $n=68)$. При визначенні товщини ендометрію були встановлені два діаметрально протилежні процеси, а саме: атрофрія (39,71\% при $n=68)$ та атипова залізиста гіперплазія (22,05\% при $n=68)$. У другій половині менструального циклу відмічено значне витончення шару ендометрія <0,6 см. У контрольній групі при проведенні ультразвукового дослідження були виявлені такі розлади: посилена перистальтика матки, розширення дугоподібного сплетення, неоднорідність субендометріального шару, а при повторному проведенні УЗД враховували дані фолікулогенезу. Фолікулярні кісти були виявлені в 10,3\% випадках у основній групі та 3,3\% у контрольній групі жінок. На момент повторного УЗД в кожному яєчнику спостерігалося 5-8 антральних фролікулів (розміри яких становили від 6,8 мм до 11,5 мм) з наявністю однієї домінанти, розмір якої становив від 18,2 до 23,4 мм. 3 метою підвищення інформативності УзД додатково проводили доплер. Таким чином, ультрасонографрія $\epsilon$ високоспецифрічним методом для визначення анатомо-фрункціональних характеристик органів малого таза, зокрема патології ендометрію у жінок зі звичним невиношуванням вагітності. Основними ультразвуковими характеристиками хронічного ендометриту, як одного з причин репродуктивних втрат, є зміни ендометрію, його структури, товщини, наявність додаткових структур (поліпів) та рідинного компоненту. Інформативність ультразвукового дослідження структурних змін з боку ендометрію при хронічному ендометриті доповнюють доплерометричні характеристики кровотоку в базальних та спіральних артеріях матки.

Ключові слова: хронічний ендометрит, звичне невиношування, УзД. 